\title{
Eco-Village Initiatives in Turkey and a New Alternative Life
}

\author{
Murat Kuruoğlu ${ }^{*}$, Hande Sanem Çınar², Funda Yirmibeşoğlu ${ }^{3}$ \\ ${ }^{1}$ Department of Civil Engineering, Istanbul Technical University, Istanbul, Turkey \\ ${ }^{2}$ Foresty Faculty, Department of Landscape Architecture, Istanbul University Cerrahpaşa, Istanbul, Turkey \\ ${ }^{3}$ Department of Urban and Regional Planning, Istanbul Technical University, Istanbul, Turkey \\ Email: ^kuruoglu@itu.edu.tr
}

How to cite this paper: Kuruoğlu, M., Çınar, H. S., \& Yirmibeşoğlu, F. (2021). Eco-Village Initiatives in Turkey and a New Alternative Life. Current Urban Studies, 9, 636657.

https://doi.org/10.4236/cus.2021.93038

Received: August 6, 2021

Accepted: September 27, 2021

Published: September 30, 2021

Copyright $\odot 2021$ by author(s) and Scientific Research Publishing Inc. This work is licensed under the Creative Commons Attribution-NonCommercia License (CC BY-NC 4.0).

http://creativecommons.org/licenses/by-nc/4.0/

\begin{abstract}
Today's settlements are typically getting less and less green with residents craving more and more for the nature. On the one hand, individuals are becoming more and more tired with big city life, and on the other, social togetherness is getting weaker and weaker. Such problems that are faced on a global scale in today's world are considered to be potential causes of greater problems in the future. With the hypothesis that building alternative sustainable living environments and increasing the number of such environments are critically important, the concept of Eco-Villages is gradually becoming popular today. Ecovillages are a type of intelligent settlements with ecological characteristics such as natural agriculture and livestock activities, thus producing their own nutrients, utilizing renewable energy systems, transforming their wastes and having a self-sufficient and collective social life. While there are successful examples of eco-villages throughout the world, the number of such examples in Turkey is rather limited. The present study analyzes certain Eco-Village initiatives in Turkey and proposes an alternative sustainable living model and its principles with reference to the question, "How can we achieve more successful Eco-Villages?", based on survey data collected from 660 participants. The proposed Smart Eco-Village Settlement Model, systematizes the city-village relationship. Social structure, physical structure, and energy-related strategies are determined for the eco-village model, and it is aimed to reorganize the spatial, sociocultural, and productive structures between the city and the village with a three-stage settlement system to be established according to its characteristics. It contributes to the economy of the region and the country through various forms of production, ensures sustainable development, and offers an alternative way of living, ensuring the sustainability of the global economy.
\end{abstract}




\section{Keywords}

Eco-Village, Ecological Settlement, Smart Eco-Village, Sustainable Settlement, Alternative Life

\section{Introduction}

The concept of ecovillage, which emerged in 1960 with a desire to form communities along with "back to the land" movement, is an ecologically, economically, socio-culturally, and spiritually sustainable settlement model. Ecovillages, which aim to reduce adverse effects (carbon footprints) to nature through design projects harmonious with nature and through voluntary participation, seek to combine ecological design projects and green technologies with participatory and supportive social structures (Cebir et al., 2019). As part of attempts to find solutions to the environmental, social, and economic problems, the eco-village movement (Güleryüz, 2013) and attempts to construct sustainable settlements have become widespread through several successful implementations in the world.

The present study focuses on the strategies about the projected ecovillage model design. Regarding this, after a review of the ecovillage settlements in the world and in Turkey, a survey study was conducted in order to find out the expectations of potential users of the projected ecovillage model. The survey questionnaire, which comprises of twenty-three question items, consists of multiplechoice and open-ended questions intended to inquire about user profiles, and physical and socio-economic expectations and preferences of users. The proposed settlement plan of the Smart Eco-village Settlement Model offers an alternative living style in Turkey and other countries.

\section{The Idea of Eco-Village and Its Principles}

In the literature, there are various definitions of eco-villages proposed by different experts. The most comprehensive of those definitions is provided by Gaia Trust, which is a foundation established under the leadership of Ross and Hildur Jackson to support the transition to a sustainable and more spiritual society in the future (URL 1, 2019). According to Gilman (2015), an ecovillage is "a human-scale, full-featured settlement in which human activities are harmlessly integrated into the natural world in a way that is supporting healthy human development, with multiple centers of initiative, and can successfully be continued in the future." Gaia Trust gathered the representatives of eco communities to develop an Eco-Village concept and to determine strategies, and that was the first step in the formation of GEN (Zeybek, 2014). Global Eco-Village Network (GEN), which was founded in 1994 after the Rio Summit held in 1992, expanded gradually. Global Eco-Village Network has connected hundreds of worldwide 
small-scale projects which had similar objectives but had been operated independently.

The fundamental axis of GEN's development program is to offer alternative solutions for transition from consumption societies to more quality living styles, better social organizations and communities which do minimum amount of damage to environment. It aims to develop sustainable technologies and businesses in order to ensure that these projects are economically sustainable; it also aims to develop an international information network and to prioritize the education of the young so that there can be an ongoing information and skills exchange among ecological villages (URL 2, 2019). As of 2011, Global Eco-Village Network has 100 members in GEN Europe and Africa, and 80 members in GEN Oceania. Also, hundreds of eco-village settlements have been established in America. GEN has been successfully realizing its mission of encouraging and promoting sustainable living models.

Jackson (1998), explains the necessary principles for the establishment of an eco-village in three dimensions as Ecological, Social, and Cultural dimensions (Gaia Education, 2006; Jackson \& Svensson, 2002; Adalılar et al., 2015):

Ecological: Applying permaculture principles, applying ecological design principles, prioritizing biodiversity, producing and consuming local and organic food, utilizing ecological constructions, renewable energy and local materials, doing green business, and doing life cycle analysis.

Social: Learning through experience, providing education and communication, living healthily, forming communities, establishing a decision-making mechanism, resolving conflicts, modernizing welfare, taking care of children and the elderly, integrating the disabled individuals into society, localizing the economy, and saving money.

Cultural: Being creative, protecting and sustaining natural cycles and different cultures, adopting a certain worldview, a certain scientific and philosophical approach, ensuring localization, and resisting globalization.

Four dimensions that constitute Eco-Villages are mentioned in the education program of Gaia Education (Ecovillage Design Education-EDE). These are Worldview, Social, Ecological, and Economic dimensions, each of which is divided into 5 modules as is shown in the sustainability circle below (Figure 1), (URL 3, 2019).

EDE curriculum offers a wide range of practical applications, ideas, and tools that have been developed during ecological trips, and within communities and urban transition environments. Gilman defines the necessary characteristics of eco-villages as the human scale, in which people know one another, the integration of human activities into the nature, and the formation of a self-sustaining settlement. Gilman also argues that the population in eco-villages should be limited to a maximum of 500 individuals (Gilman \& Gilman, 1991). Among the most important activities in eco-villages are consuming less energy, preventing environmental pollution by reducing waste, invigorating the local economy by 


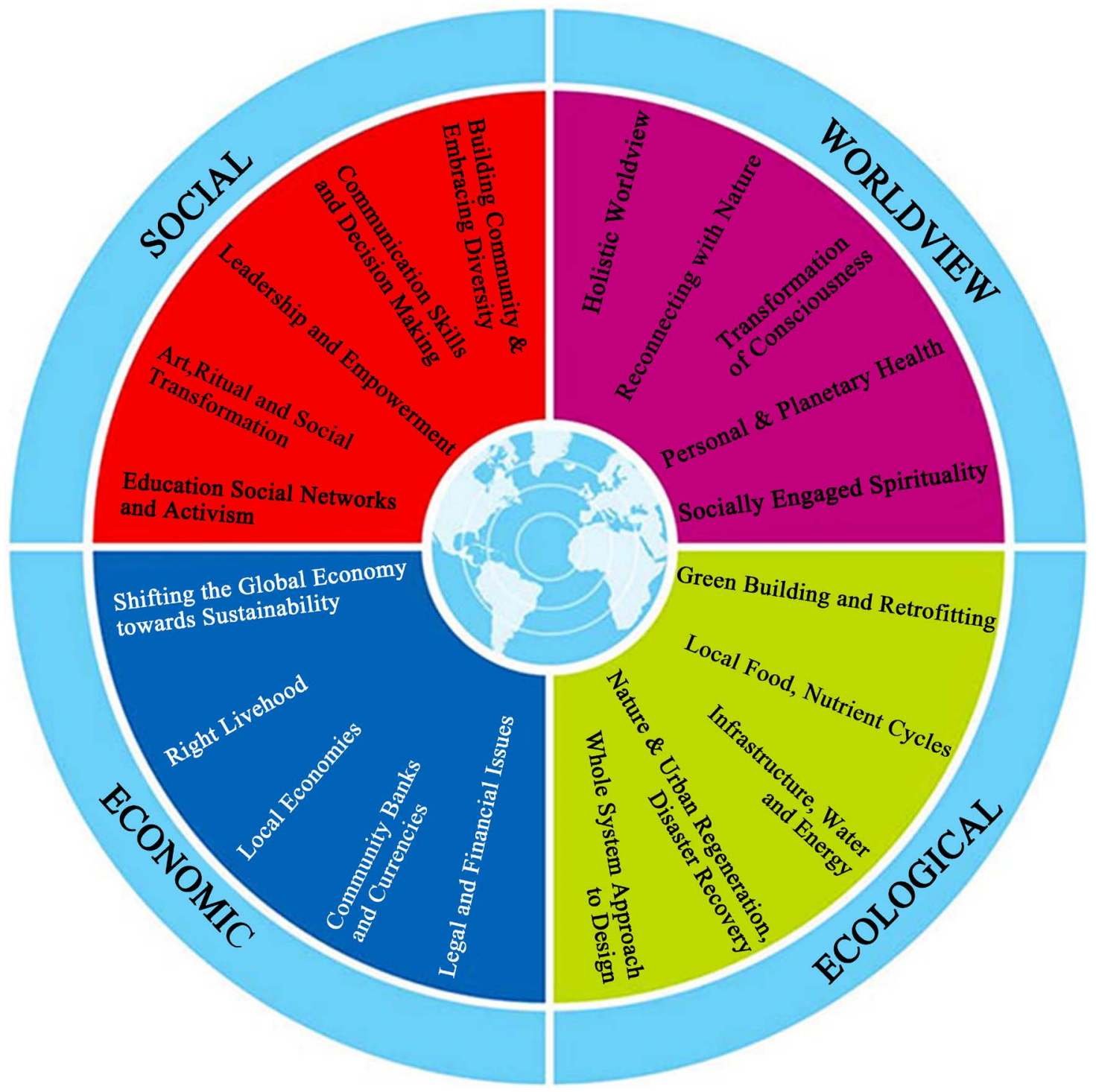

Figure 1. Sustainability dimension in ecovillage design education (EDE) (URL 3, 2019).

developing local resources, establishing a social economy scheme based on cooperation, establishing communities living harmoniously, establishing a participatory decision-making scheme, producing local organic food, applying permaculture, utilizing ecological architecture and renewable energy, and managing wastes (URL 4, 2019; Güleryüz, 2013).

Eco-Villages are grouped under three categories according to their characteristics; population and distance, design philosophy, and community type (Takeuchi, Namiki, \& Tanaka, 1998; Jackson \& Svensson, 2002; Meijering et al. 2007).

Eco-Villages established based on population and distance can go up to 100 hectares in size (Takeuchi, Namiki, \& Tanaka, 1998) (Table 1).

- The settlements in the urban fringe are more populated and larger in size, and they are in direct connection with the city. The agricultural lands are reactivated, and additional income is earned through land leasing, and social 
Table 1. Eco-villages formed according to population and distance (adapted from Takeuchi et al., 1998).

\begin{tabular}{|c|c|c|c|}
\hline & URBAN FRINGE & RURAL FRINGE & NATURAL AREA \\
\hline Population Density & 100 persons $/$ ha & 10 persons /ha & 1 person/ha \\
\hline Total Population & 10,000 - 60 villagers & 1000 & $\begin{array}{l}100 \text { - } 60 \text { villagers } \\
40 \text { visitors }\end{array}$ \\
\hline Land Use & $\begin{array}{c}70 \text { ha rural land use (20 ha hobby gardens) } \\
\text { 30ha residential area }\end{array}$ & $\begin{array}{l}90 \text { ha rural land use } \\
10 \text { ha residential area }\end{array}$ & $\begin{array}{l}99 \text { ha rural land use } \\
1 \text { ha residential area }\end{array}$ \\
\hline Characteristic & Sharing between villagers and urbanites is important & Ecological network & $\begin{array}{l}\text { High communication links } \\
\text { Long-term accommodation }\end{array}$ \\
\hline
\end{tabular}

interaction is made possible through the knowledge and wisdom of those who live in the village.

- The most important characteristic of Eco-Villages in rural areas is the creation of an ecological network through rural landscaping resources.

- Eco-Villages in the natural environment are the least populated.

- Eco-Villages established based on a design philosophy are designed according to four different orientations (Gaia Education, 2006; Jackson \& Svensson, 2002; Adalilar et al., 2015):

- Ecologically oriented Eco-Villages seek to do minimum damage to natural environment and to develop a village harmoniously integrated into the nature in the future by doing sustainable agriculture analyses.

- Socially oriented Eco-Villages are cooperative housing organizations which include shared utility areas in the center.

- Culturally oriented Eco-Villages have a central area for cultural activities such as theatre, dance, music, meetings and gatherings.

- Spiritually oriented Eco-Villages have a meditation area which is easily accessible to everyone.

Eco-Villages established based on community type are voluntary communities composed of individuals who have decided to share time and space with each other. Meijering et al. (2007) divides voluntary communities into four as religious, ecological, communal, and practical communities (Giani, 2011).

- Religious communities are based on a strong ideological bond to the same religion among all members of the community.

- Ecological communities seek to achieve minimum consumption according to their food and energy production and maximum self-sufficiency.

- Communal communities seek to create strong bonds among the members.

- In Practical Eco-Villages all the materials and opportunities that make life 
easier.

- and cheaper are shared among the members (Meijering, 2006 and Giani, 2011).

\section{Eco-Village Initiatives}

According to April 2010 data of the Global Eco-Village Network, the distribution of Eco-Villages in the world is as follows (Zeybek 2014): 36\% Europe, 25\% USA, 14\% Latin America, 9\% Australia, 6\% Canada, 5\% Africa, 3\% South Asia, $1 \%$ Middle East, and 1\% Other.

The situation in Turkey is rather different. While there was a worldwide boom in eco village movements along with the increasing sustainability efforts through the end of the 1980s, there was a reverse movement in Turkey. This reverse migration movement from rural areas to the city in Turkey caused an erosion of social and cultural characteristics, traditional architecture, traditional knowledge of agriculture and husbandry peculiar to traditional rural living style on the one hand, and led to several problems in the city such as population density, social communication deficiencies, a cultural erosion, a shortage of natural resources, and environmental pollution on the other.

The eco-village initiatives in Turkey in the later periods are generally regarded as small-scale businesses. Today they are generally agriculture-and-tourism-oriented farms which produce agricultural products and distribute products all over Turkey and which function as tourist destinations with guest houses. Large-scale eco-village initiatives, on the other hand, have not been successful due to factors such as insufficient equipment and poor adaptation of newcomers to rural life (Güleryüz, 2013).

The first eco-village initiative in Turkey was put forward by a group of mountaineers from Middle East Technical University through the end of the 1990s. They named the initiative 'Hocamköy'. The group aimed to establish a sustainable rural model of living in association with the local people by combining the traditional wisdom of Anatolian people with academic knowledge (Asimgil, 2017). Nevertheless, this eco-village initiative failed to be developed. Some eco-villages in Turkey are members of Global Ecovillage Network (GEN); yet, Turkey established local institutions, Turkish Ecological Settlements Network (TESN) and Eco-Villages Communication Network (ECN), in order to gather all Eco-Village initiatives under one roof and solve the problems faced. The objectives of TESN, which was founded by the members of Promoting Ecological Life Association, are promoting ecological settlements, contributing to the development of their economies, establishing a network to share experiences, and ensuring that the network gains strength through training programs and festivals. ECN, which was established by individuals who got together during the meetings in Ankara, İstanbul, Kırıkkale, Foça, and Fethiye and who want to build an eco-village settlement, provided opportunities to exchange considerable information. However, these organizations are not active today. Wheat Promoting Ecological Life 
Association has been active since 1990, though. The objectives of the Wheat Association are defined as raising awareness and sensitivity among individuals and within society about ecological life and promoting living styles harmoniously integrated into nature so as not to upset the ecological balance. In order to achieve such objectives, Wheat Association seeks to contribute to sustaining traditional agricultural production as in villages, promoting and popularizing sustainable agricultural methods that do not pose a threat to human health, and redefining human needs in accordance with ecosystem cycles (URL 5, 2019). Ecovillage settlements in Turkey, the initiatives of which gained a momentum during the 2000s, are predominantly located in the Aegean and Mediterranean regions (Figure 2). Yet, factors such as social and economic problems, social security, certain insufficiencies in the healthcare sector, and neglect of agriculture, which is the backbone of rural life, have a negative impact on eco-village initiatives (URL 6, 2019).

\section{Some Eco-Village Initiatives in Turkey}

Some Eco-Village initiatives and their features have been investigated below, including Güneşköy-Kırıkkale, Dedetepe Ecological Life Farm, Çamtepe Ecological Life Center, Eko-Foça Eco-Village-İzmir, Marmariç Eco-Settlement-İzmir, Dutlar Collective House-İzmir.

- Güneşköy-Kırıkkale It was established by a group of 9 members as the first environmental cooperative association in Turkey. After the acquisition of 7.5 ha of public property in Hisarköy in the Yahşihan district of Kırıkkale province, in 2005 it was declared to be the first ecological settlement in Turkey to be a member of European Eco-Villages Network (GEN-Europe). In the beginning, the activities were focused more on organic farming, permaculture, and ecological sustainability, and today the cooperative association seeks to

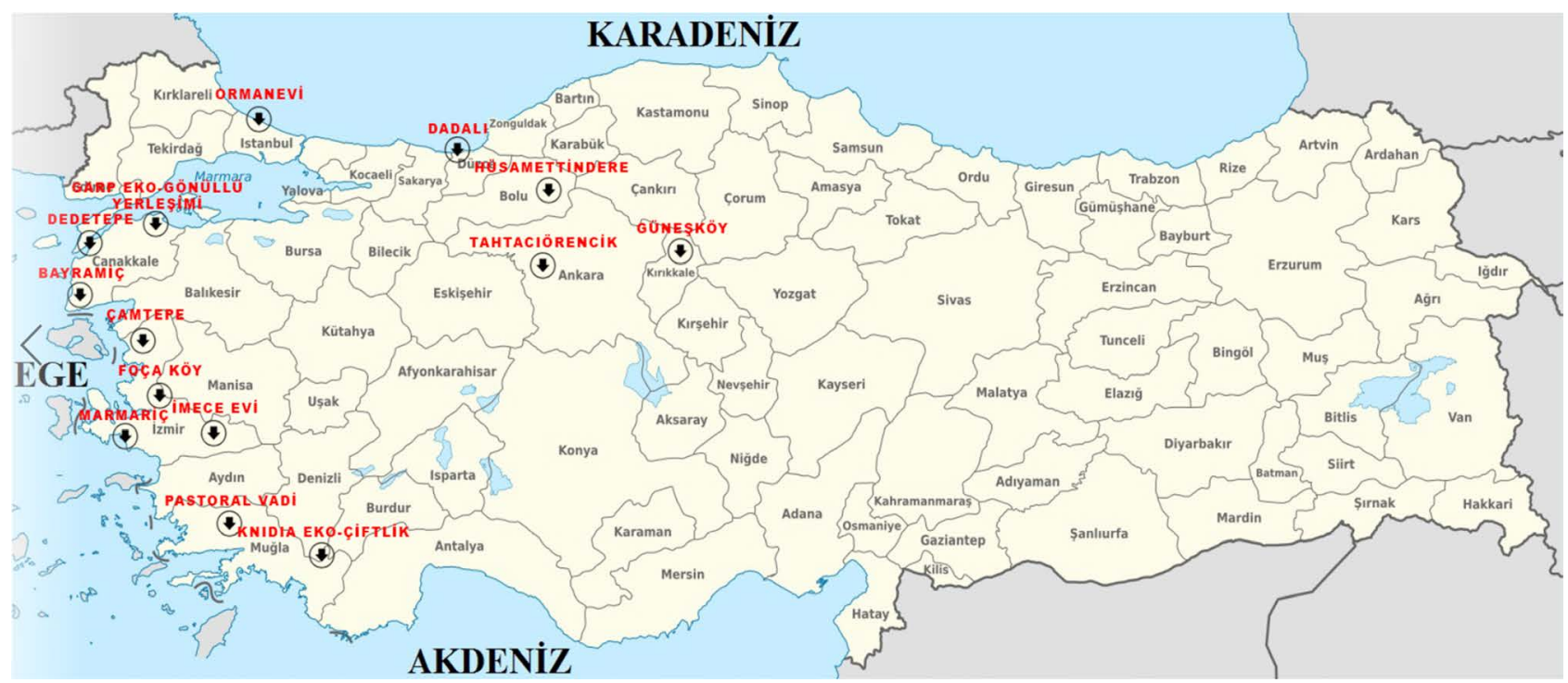

Figure 2. The regional distribution of ecological settlement initiatives in Turkey (prepared within the scope of the study). 
develop and share rural life experiences that are sustainable and harmonious with the nature. It is aimed to teach villagers in the area that the transition to a sustainable life is not that easy in a land surrounded by arid hills and to inspire the villagers who do not have access to certain opportunities due to the distance to the city center (URL 7, 2019). Among the aims, there are also activities such as producing sample products so that people can acquire information and culture, marketing, and organizing scientific and educational activities (Kara, 2014).

- Dedetepe Ecological Life Farm The Dedetepe Ecological Life Farm is located next to the Çanakkale and Balıkesir borders. Organic farming is carried out in Dedetepe Farm and products are sold via web sources. Olive and olive oil production is an important source of income. The nutritional needs of inhabitants of the settlement are met. The dining hall can be considered as a socializing area. The cellar located under the ground kitchen can also be seen in traditional practices. In this settlement system; there is no refrigerator, dishwasher or television and meals are cooked on wood fire. The Montessori Education Model, which is based on individual education, is applied in the school located in this settlement. There is a wide classroom as a reflection of the education model inside the masonry structure created using wooden materials (Güleryüz, 2013).

- Camtepe Ecological Life Center It was founded in 2010 by the members of the Wheat Association for Supporting Ecological Life in Küçükkuyu, Ayvacık/ Çanakkale province on the foothills of Kaz Mountains (Güleryüz, 2013). "Rather than being a museum, it aimed to show that it is possible to have a life that is at peace with nature, within itself, and whose cycles are completed" (URL 8, 2019). "It aims to create a rural model that stands with its own resources" (URL 9, 2019). In the settlement area, a single common-use residence ("cohousing") was designed for accommodation of people who want to leave their life in the city and live in the village. It was built in Küçükkuyu with ecological principles. Çamtepe Ecological Life Center building contains all traditional architectural elements. Locally obtained limestone was used in the construction of the building and $60 \mathrm{~cm}$ stone walls were built with this material. Several activities are organized in Çamtepe throughout the year. These activities could be about a wide range of themes such as nature, ecological architecture, organic farming, yoga techniques, and so on. Those who participate in the activities pay a fee for accommodation and training. The income earned from the activities is used both for the building in Çamtepe and for other expenses of Wheat Association (Güleryüz, 2013).

- Eko-Foça Eco-Village-İzmir It was built by Tunca Bökesoy in 2001 on a 3.5-ha land, $55 \mathrm{kms}$ away from İzmir. Eko-Foça eco-village initiative is an example of sole-proprietorship; it is a one-person-owned initiative. The proprietor decided to construct 10 buildings designed in a traditional architectural character considering ecological principles and made an offer to his 
friends to live in the village. For a while, 4 families moved to the village and lived there; however, today there are no active residents in the village (Güleryüz, 2013). Eko-Foça is a natural living village. It is a settlement which has been built with a nature-first approach based on participatory and cooperative principles, which aims to establish a social and economic form of life as an alternative to the present system, and which seek to protect not only natural environment but also the historical and cultural heritage (Erdinç \& Kariptaş, 2015).

- Marmariç Eco-Settlement-İzmir was established in Dernekli village in Bayındır, İzmir to revive the village, which was abandoned 20 years ago, based on permaculture principles and thus to build a model sustainable settlement. The 2.2-ha land located on the Ida (Kaz) Mountains is one of the longest established ecological settlements (Kara, 2014). The settlement, which has its own association called 'Marmariç Ecological Life Association' and also an institute of its own called 'Turkish Permaculture Research Institute', prioritizes both social and ecological activities of permaculture and therefore also calls itself 'Marmariç Permaculture' (URL 10, 2019).

- Dutlar Collective House-İzmir In 2007, a group of 10 people came together under the name of the "Dutlar Collective" initiative to revive the abandoned village of Dutlar in the Menemen district of Izmir, an abandoned village on an area of 80 decares, and to protect the traditional architectural heritage and to create an ecological and sustainable life. Collective House is defined as a "farm and awareness school", not an "Eco-Village". The main purpose is to transform the village of Dutlar, the abandoned old village into an "Eco-Village". Collective House was established as a camp in 2007 and later turned into a farm. A guesthouse building made of straw bale was built in the area of the Collective House. Today, life continues in the building, which consists only of wood, straw bale and earthen plaster. There are areas around the Collective House land to protect the forest area and natural woodland feature. In the reconstruction plan, the area where the abandoned Dutlar village is located was specified as a "rural settlement" area. Collective House is not physically close to other village settlements in the vicinity. It can be said that it was isolated from the environment and even separated from the land of Dutlar Village, which was planned to be renewed. Currently, there is only one building belonging to the Collective House. The single room in this structure consisting of stone and wood is used for many functions such as guesthouse, resting room, bedroom, kitchen, and all vital activities take place in this area (Güleryüz, 2013).

When ecovillage examples from Turkey are summurized that (Table 2);

- Vernacular (local architectural features, local traditional architectural techniques) and innovative approaches are used as an architectural approach,

- Most of them are designed on an existing rural settlement and the buildings in that area are used in the design, 
Table 2. Eco-villages' features in turkey.

\begin{tabular}{|c|c|c|c|c|c|}
\hline $\begin{array}{l}\text { NAME OF THE } \\
\text { ECOVILLAGES }\end{array}$ & $\begin{array}{l}\text { ARCHITECTURAL } \\
\text { APPROACH }\end{array}$ & $\begin{array}{l}\text { HOUSING } \\
\text { TYPE }\end{array}$ & BUILDING PARTS & $\begin{array}{l}\text { CONSTRUCTION } \\
\text { MATERIALS }\end{array}$ & TYPE OF ENERGY \\
\hline \multirow{2}{*}{$\begin{array}{l}\text { Güneşköy } \\
\text { Eco-Village }\end{array}$} & Vernacular & & Meeting Area & Masonry & \multirow{2}{*}{ Solar Greenhouse } \\
\hline & Innovative & & Greenhouse & Straw Bale & \\
\hline \multirow{8}{*}{$\begin{array}{l}\text { Dedetepe } \\
\text { Ecological Life } \\
\text { Farm }\end{array}$} & Vernacular & Log Houses & Houses (5) & Wood & \multirow{8}{*}{$\begin{array}{l}\text { An energy system created with } \\
\text { solar panels and wind }\end{array}$} \\
\hline & Innovative & Nomad Tent & Meeting Area & & \\
\hline & & & Nomad Tent & & \\
\hline & & & School & & \\
\hline & & & Bath & & \\
\hline & & & Dining Hall & & \\
\hline & & & Toilet & & \\
\hline & & & Market & & \\
\hline \multirow{2}{*}{$\begin{array}{l}\text { Çamtepe } \\
\text { Ecological Life } \\
\text { Center }\end{array}$} & Vernacular & Shared Housing & Shared Housing (1) & Adobe Stone & \multirow{2}{*}{$\begin{array}{l}\text { A central system established by } \\
\text { distributing the water heated by } \\
\text { wood to the radiators }\end{array}$} \\
\hline & Innovative & & Kitchen Area & Reed & \\
\hline \multirow{4}{*}{$\begin{array}{l}\text { Eko-Foça } \\
\text { Eco-Village }\end{array}$} & Vernacular & Village Houses & $\begin{array}{l}\text { Houses ( } 3 \text { blocks/in } \\
\text { total } 9 \text { pieces ) }\end{array}$ & Stone & \multirow{4}{*}{ Solar Energy } \\
\hline & & & Meeting Area & Half-Timbered & \\
\hline & & & & Masonry & \\
\hline & & & & Wood & \\
\hline \multirow{4}{*}{$\begin{array}{c}\text { Marmariç } \\
\text { Eco-Settlement }\end{array}$} & Vernacular & Stone Houses & Meeting Area & Slate Stone & \multirow{4}{*}{$\begin{array}{l}\text { Only houses are heated with solar } \\
\text { panels. Prity, the stove system } \\
\text { produced in Bulgaria, is used to } \\
\text { heat the spaces. The heat } \\
\text { generated by the radiators is } \\
\text { dissipated. }\end{array}$} \\
\hline & Innovative & Wood Bungalows & Old School Building & Wood & \\
\hline & & & Old Public Housing & Earth Plaster & \\
\hline & & & Bungalows (4) & & \\
\hline \multirow{3}{*}{$\begin{array}{c}\text { Dutlar Collective } \\
\text { House }\end{array}$} & Vernacular & Shared Housing & Shared Housing & Straw Bale & \multirow{3}{*}{$\begin{array}{l}\text { An energy system created with } \\
\text { solar panels and bicycles. }\end{array}$} \\
\hline & & & Common Area & Wood & \\
\hline & & & Dining Hall & Masonry & \\
\hline
\end{tabular}

Table developed within the scope of the research.

- In the examples where local materials are used as building materials, mainly straw bales, wood and adobe are used,

- Renewable energy sources are used considering environmental sustainability,

- Ecovillages generally consist of a common area and shared buildings,

- It is seen that the samples without settlement disappeared over time.

\section{Eco-Village Settlement Model Proposal}

According to Dawson each eco-village settlement has a different target audience and establishment methods. The settlements differ from one another in terms of location, land choice, geographical characteristics, and founding purposes 
(Asımgil, 2017). There are various factors to be considered while establishing eco-villages such as the settlement plan, construction of buildings, the selection of individuals to live in the settlement, and the determination of decision-making mechanisms and the management (Barton, 2000). Barton proposes seven suggestions for the planning of ecological and sustainable settlements, which are as follows (Barton, Marcus, \& Richard, 2003): the founders and residents of the settlement should take initiative, a common vision should be built and defined clearly, locality and its importance should be emphasized and adopted, new perspectives should be developed, a coordinated settlement plan and program should be set, and immediate and determined actions should be taken. In the planning phases of eco-villages, the natural, cultural, social and economic resources of the village which will contribute to eco-tourism are critical elements in the development dynamics of the eco-village. All parameters of those resources should be considered, and planning steps should be taken accordingly during the decision-making process (Tuğun \& Karaman, 2014; Aydın Yönet \& Yirmibeşoğlu, 2019).

\section{Eco-Village Settlement Model Systematic}

The settlement plan of the Eco-village Settlement Model, which offers an Alternative Living Style, proposed within the scope of the present study after a thorough analysis of previous research is determined as follows: Urban Fringe (5000 - 15,000 persons), Rural Area (2000 - 500 persons, 1 hour away from the city), Natural Area (500 - 100 persons, close to the village). It is aimed to establish a systematic and organic link between the village and city through the population structure and distance system (Cebir et al., 2019; Kuruoğlu et al., 2019; Akoğlu et al., 2019) (Figure 3).

Considering the scope of the model, decisions were made, and planning steps were determined based on the results of the survey conducted to 660 individuals within the body of Housing Research and Training Center of Istanbul Technical University in 2019.

The survey has 23 questions that reveal the basic components of the settlement, such as economic structure, social structure, physical structure, transportation, and building materials. The results of the survey are as follows (Table 3).

Willingness to live in the Eco-Village Settlement is $88 \%$. Agriculture is one of the main sectors of eco-villages. According to the survey, $63 \%$ of the participants chose agriculture as an answer to the question about the determination of the economic sector of the village settlement. In accordance with permaculture principles of agricultural production, it is accepted that natural farming methods without agricultural drugs and chemical additives will be used. The preferred region for the Eco-Village is the Aegean region (51\%).

As an answer to the question about the basic livelihood of the eco-village, in which the participants selected from multiple options, $63 \%$ of the participants opted for "working in a job other than/independent from the eco-village," while 


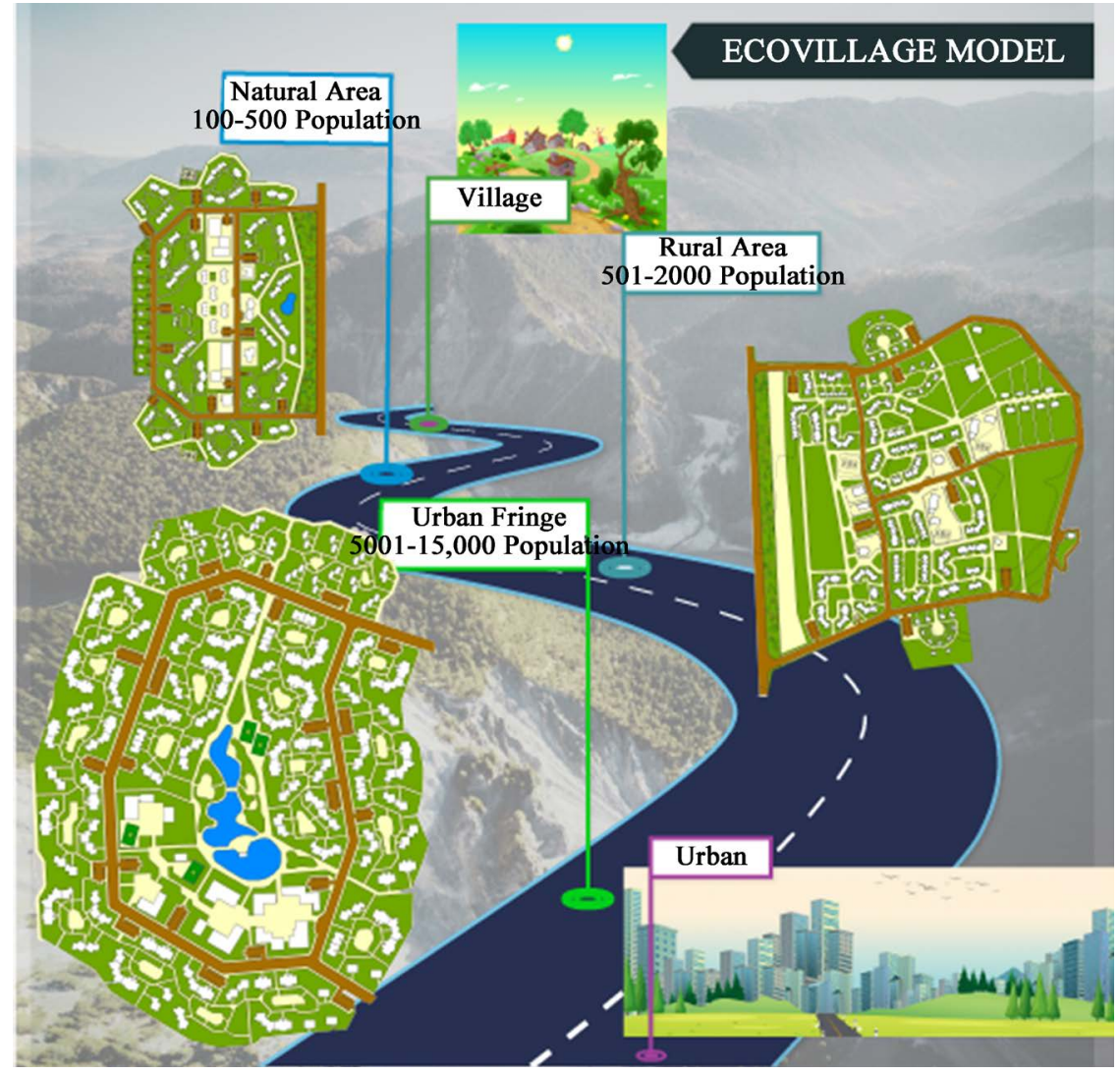

Figure 3. Eco-Village Settlement Model (Cebir et al., 2019; Kuruoğlu et al., 2019; Akoğlu et al., 2019).

$54 \%$ selected "working in a job in the settlement." Therefore, it is expected that the participants of the eco-village will be able to choose from various options such as to continue their work outside the village or to have the opportunity to work in the village workshops, in agriculture, in raising livestock, or in the production of activities such as bakery or ecotourism.

As for the answer to the multiple-choice question regarding the sharing of income obtained from the various products of the eco-village, $65 \%$ of the participants suggested that the income should be used for the development of the ecovillage.

As an answer to the question about the ownership status of the housing in the eco-village, $54 \%$ of the participants chose homeownership; $14 \%$ were in favor of cooperatives; 7\% chose to be tenants and lodging; others chose "timeshare properties," "free of charge," and "social facility with payment" as answers.

Transportation between the city and the eco-village is important. It is expected that transportation in the eco-village will be conducted with bicycles (53\%), public transportation and eco-vehicles.

As an answer to the question about the preferred house size in the eco-village, $43 \%$ chose $80 \mathrm{~m}^{2}$. The houses are expected to be designed as $2+1$ residential unit, the sizes of which range from 40 to $80 \mathrm{~m}^{2}$. 
Table 3. Survey Results

\begin{tabular}{|c|c|c|}
\hline \multirow{2}{*}{$\begin{array}{l}\text { SURVEY RESULTS } \\
\text { Willingness to live in the Eco-Village Settlement }\end{array}$} & \multicolumn{2}{|c|}{660 Persons } \\
\hline & $88 \%$ & Yes \\
\hline Type of Eco-Village & $67 \%$ & Ecological \\
\hline The Preferred Region for the Eco-Village & $51 \%$ & Aegean \\
\hline The preferred location & $51 \%$ & Rural Area \\
\hline The Preferred Economic Sector in the Eco-Village & $63 \%$ & Agriculture \\
\hline \multirow[t]{2}{*}{ The Must for the Eco-Village } & $49 \%$ & Natural Farming and Husbandry \\
\hline & $30 \%$ & Collective Living Consciousness \\
\hline Means of Transportation & $53 \%$ & Vehicles without engines, e.g. bicycles \\
\hline \multirow[t]{4}{*}{ The preferred activities to be done } & $72 \%$ & Agricultural production \\
\hline & $53 \%$ & Art Activities \\
\hline & $53 \%$ & Training Activities \\
\hline & $46 \%$ & Production of Manufactured Goods \\
\hline \multirow[t]{4}{*}{ The Desired Activities in the Eco-Village } & $79 \%$ & Workshops \\
\hline & $73 \%$ & Library \\
\hline & $70 \%$ & Healthcare Center \\
\hline & $63 \%$ & Sports Facility \\
\hline \multirow[t]{4}{*}{ Ownership } & $54 \%$ & House Owner \\
\hline & $14 \%$ & Cooperative \\
\hline & $9 \%$ & Free of Charge \\
\hline & $7 \%$ & Rental, Lodging \\
\hline \multirow[t]{4}{*}{ The Preferred House Size } & $43 \%$ & $80 \mathrm{~m}^{2}$ \\
\hline & $26 \%$ & $120 \mathrm{~m}^{2}$ \\
\hline & $20 \%$ & $40 \mathrm{~m}^{2}$ \\
\hline & $21 \%$ & $60 \mathrm{~m}^{2}$ \\
\hline The Number of Rooms & $47 \%$ & $2+1$ \\
\hline \multirow[t]{2}{*}{ The number of storeys } & $61 \%$ & 1-storey \\
\hline & $39 \%$ & 2-storey \\
\hline \multirow[t]{3}{*}{ The building material of the house } & $37 \%$ & Local Materials and Methods \\
\hline & $30 \%$ & Wooden \\
\hline & $25 \%$ & Stone or Briquet \\
\hline Share of Incomes in the Eco-Village & $65 \%$ & It should be used for the development of the Eco-Village \\
\hline
\end{tabular}

In the eco-villages, the kitchen, bathroom, and toilet, which can be both public and individual areas, are chosen by the participants to be individual areas. Some of the participants also demand that the use of the kitchen can be shared. According to housing choices of participants; 1 - 2-stories, $80-120-40 \mathrm{~m}^{2} ; 2+$ $1,3+1,1+1$, studio options are, respectively, preferred. It is important to display all the options to address everyone.

The features of the proposed Smart Eco-Village Settlement Model according 
to the results of this survey are as following.

\section{Housing Size, Plan Types and Ownership}

In the proposed Eco-Village Settlement Model, housing unit clusters are formed based on size $\left(20-40-60-80 \mathrm{~m}^{2}\right)$ or ownership (homeowner, cooperative, lodging, tenant, and timeshare), and the clusters are built in such a way to have courtyards in order to give the residents an opportunity to develop neighborhood relationships. Housing types have been developed depending on the traditions of Turkish people. Different selection alternatives are offered (Table 4).

\section{Model Proposal}

The areas which should be given the most importance are the agricultural areas, which are critically important in terms of raising an awareness of collective living and production. The eco-village has facilities that are requested by the participants such as workshops, hobby gardens, healthcare facilities, sports facilities, festival areas, art centers, training centers, spiritual training units, and other necessary equipment to meet the needs of the population according to the Regulation for Spatial Plan-Making. In the village, the transportation system design is planned to be a bicycle-and-public-transportation-based one; a transportation model which prioritizes bicycles, engineless vehicles and public transportation has been developed, and a car park solution has been provided at the entrance of the eco-village or in front of the housing clusters. The services that can be offered to visitors of the village can be summarized as accommodation, healthcare services, communication, catering facilities, visitor information centers, festivals, local products, traditional and cultural activities, active participation in village social life. The figure below presents the plan of the settlement to be built in the rural area (Figure 4).

Eco-Village Settlement Model is a model in which natural agriculture and husbandry practices without pesticides and additive agents are carried out in accordance with permaculture principles; and thus, it is a model which produces its own food. It is also planned that in the village workshops there will be activities such as producing natural agricultural and animal husbandry products and bakery activities based on processing grain products, or eco-tourism activities.

Moreover, the Eco-Village Settlement Model is projected to be an ecological, self-sufficient smart settlement which uses renewable energy systems, produces its own electricity and sells surplus electricity to the system, supplies its own water, recycles wastes, carries out measurements in houses with smart technologies, controls irrigation, waste and energy management with automation and has a collective social life. It is planned that the eco-village has a cooperative-based proprietorship model in which the members are given options such as homeownership or tenancy, that the settlement is built in the rural area which is maximum 1 hour away from the city, as has been most popularly preferred by 
M. Kuruoğlu et al.

Table 4. Housing types.

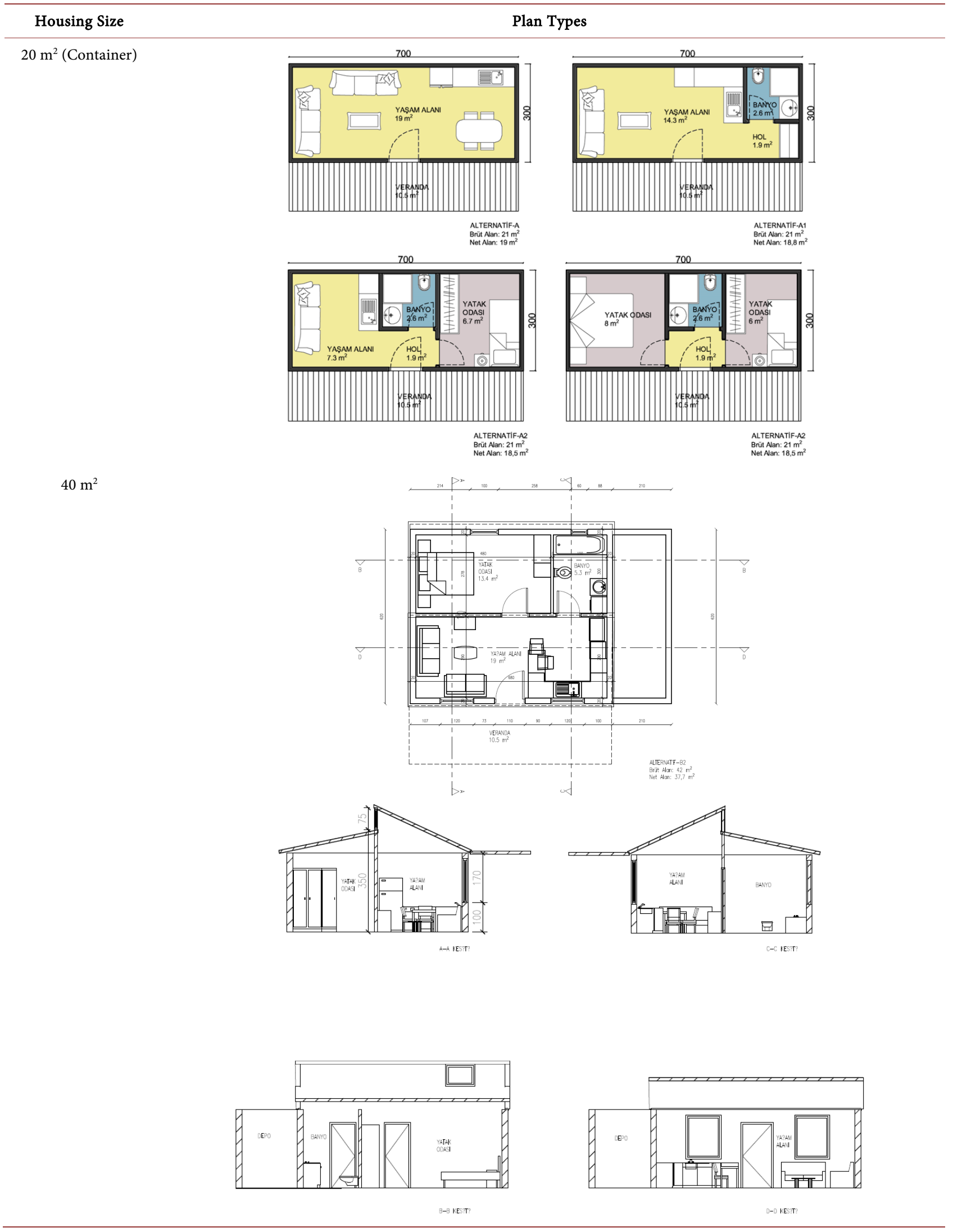




\section{Continued}

$60 \mathrm{~m}^{2}$
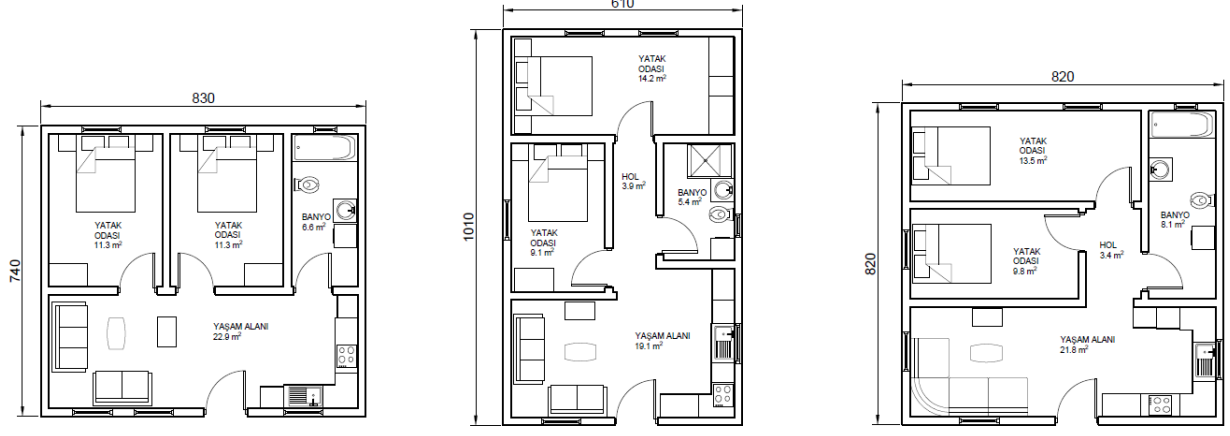

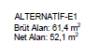

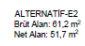

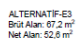
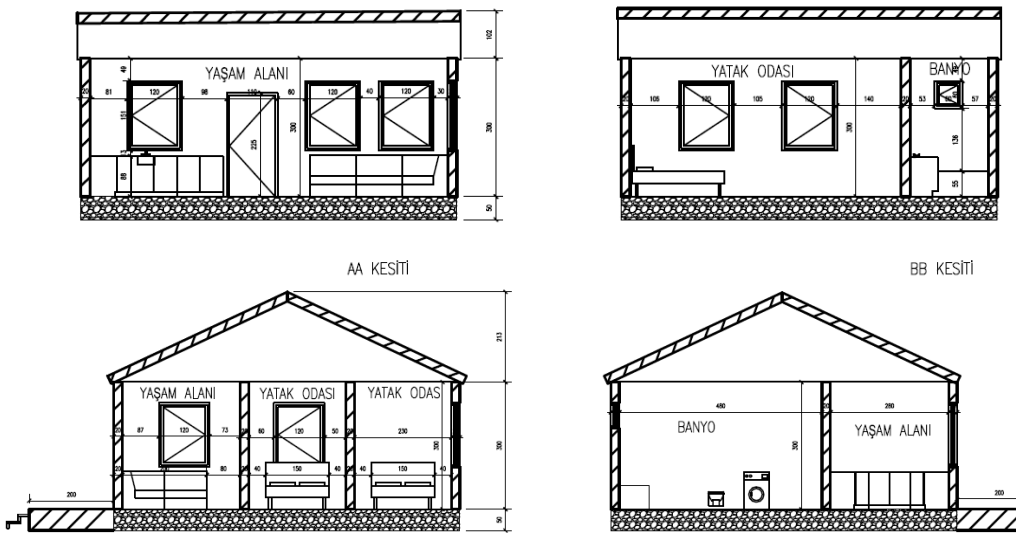

BB KESiTi

CC KESIT

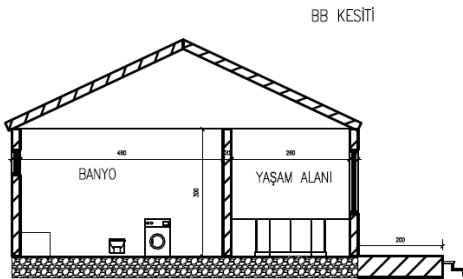

DD KESTT

$80 \mathrm{~m}^{2}$

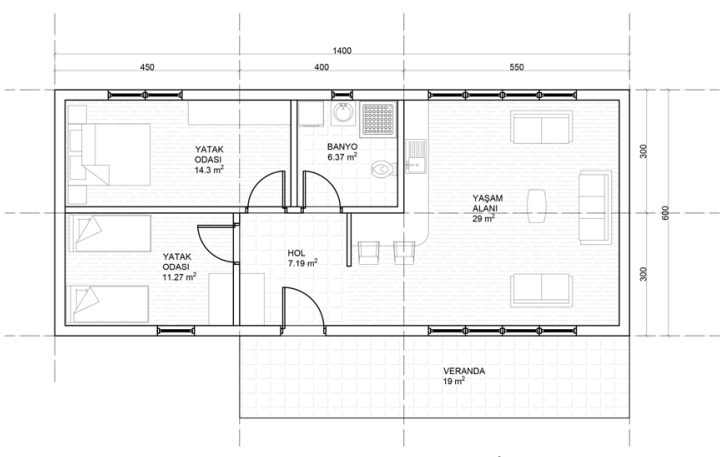

TIP-1 PLAN

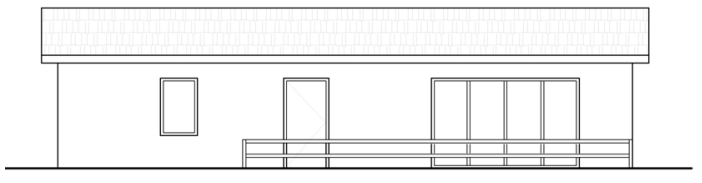

TIP-1 ÖN CEPHE

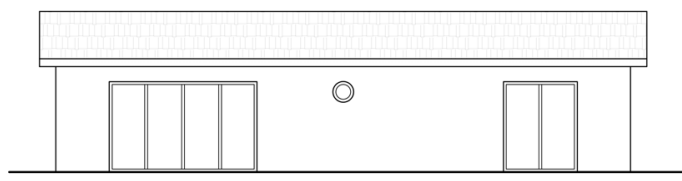

TIP-1 ARKA CEPHE

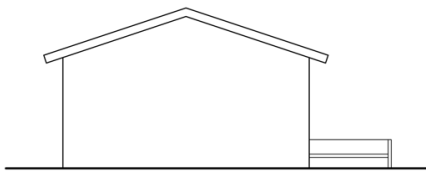

TIP-1 SOL YAN CEPHE

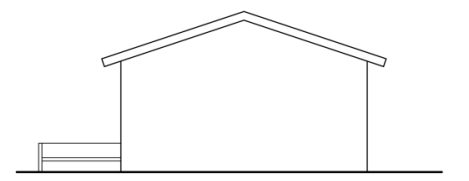

TIP-1 SAĞ YAN CEPHE 
M. Kuruoğlu et al.

\section{Continued}

$80 \mathrm{~m}^{2}$

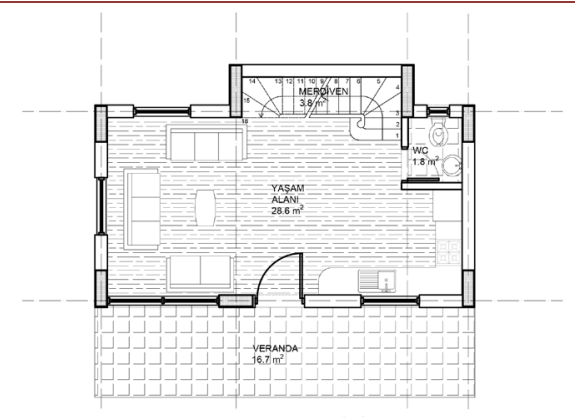

GIRIŞ KAT PLANI

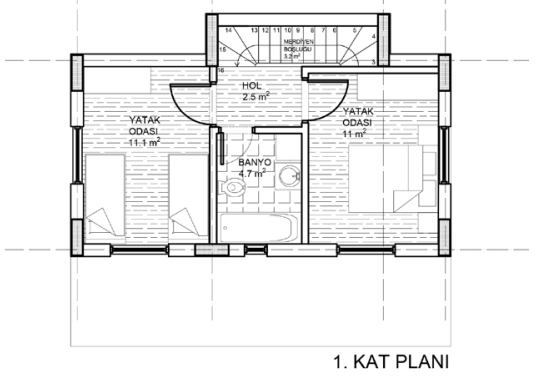

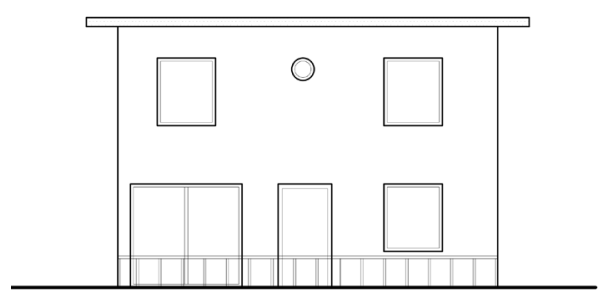

ÖN CEPHE
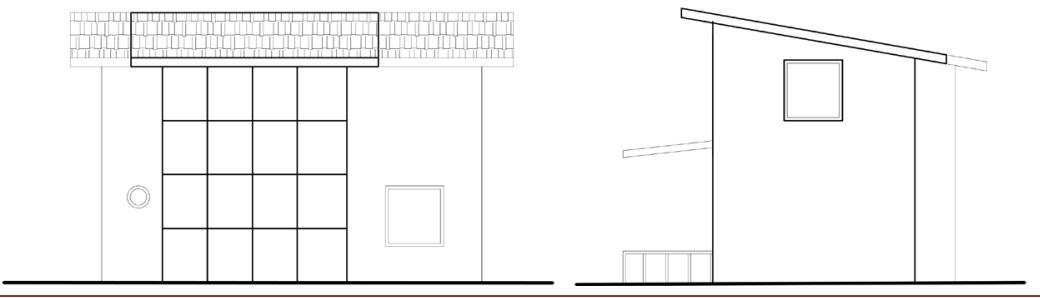

Housing plans developed within the scope of the study.

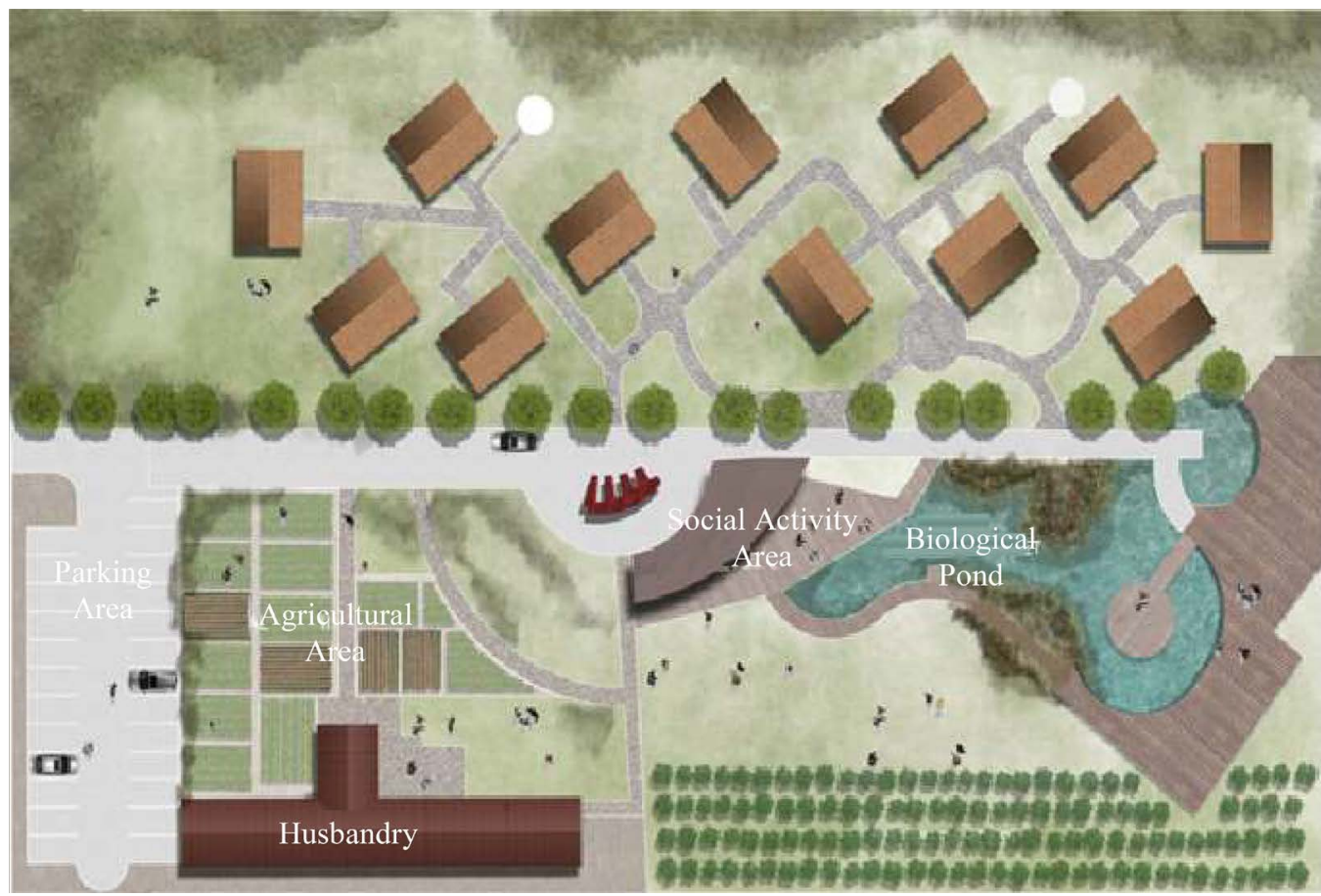

Figure 4. The Smart Eco-Village Settlement Model Proposal (Çınar et al., 2019). 
the survey participants, and that the transportation in the eco-village is provided by eco-friendly vehicles such as bicycles and electrical vehicles.

\section{Model Aspects}

It is aimed that the projected eco-village is a settlement model,

- whose economy is based on trust, transparency, and mutual support,

- which is cooperative based,

- which is founded using a cooperative method which allows equal say to all members,

- which produces its own food and sells the natural agricultural and animal husbandry products it produces,

- which produces its own energy and sells the surplus energy,

- which integrates the water and waste of the building into the energy system and energy management system with the automation system, making heat and radiation measurements using smart technologies,

- which provides job opportunities for the Eco-Village residents (Agriculture, husbandry, Workshops, etc.), and

- which is economically self-sufficient and sustainable.

As a result, with the proposed model it is aimed to create a sustainable, integrated system in all eco-village initiatives with different social, economic and ecological systems. By adopting the principles of a nature-based, asset-oriented, balanced, sustainable, accessible, clean and renewable energy; and serving different purposes in urban, rural and natural areas; an understanding that embraces the sustainability of an innovative, entrepreneurial, productive, organized, educated, sharing culture, is built. It is aimed to create an eco-village model that can integrate with the whole community, especially children, youth and women.

Through the implementation of this model, it is aimed to revive the economic, social, and cultural relationships between the city and the village, and to bring together the knowledge base of professional disciplines and the wisdom of the locals (Cebir et al., 2019; Kuruoğlu et al., 2019).

\section{Conclusion and Review}

Eco-villages are gaining more and more importance today as ecologically, economically, and socio-culturally sustainable human settlements. They create environments where local and natural resources are used, socio-cultural structure is diversified, and healthy, secure, and quality living environments are formed.

In recent years, scientists have been working on new solutions and new living alternatives that reduce the negative effects of cities and carbon emissions. These studies include policy, economy, land use, agriculture, ecological settlements, transportation, energy, climate, etc. (Chai et al., 2020; Smith et al., 2014; Zhang et al., 2020; Zhao et al., 2018; Moravčíková \& Fürjészová, 2018).

For example, Chai, Fu, and Wen (2020) developed a multiregional hybrid model which is composed of a partial equilibrium module, including economy and trade, energy and power, transportation, agriculture, forestry, and land use. It also has 
a soft link with the simplified climate and air pollution model by using the impact/adaptation cost curves.

In their study on ecovillages in Hungary, Moravčíková and Fürjészová (2018) mention that ecovillages offer an alternative life. In the study, the main objective is to characterize, analyze and eventually compare types, trends and problems in the development of ecovillages and to discuss the possible impacts and effects of eco-village movement on sustainable rural development. They used interviews, observation and inquiry for data collection, document analysis, content analysis of different sources, and analysis of foot marks.

Dias et al. (2017) stated in their research that "Eco-villages are communities that carry out an array of sustainable practices and aim to influence society as models for alternative lifestyles".

Westskog et al. (2018) carried out a study in the Hurdal Ecovillage in Norway and stated that the residents built their own houses and the eco-village was largely isolated from the local community.

Smith et al. (2014) declared that semi-urban settlements are places where large numbers of people come together, even voluntarily, in special-purpose settlements that lack many of the characteristic of cities. These deficiencies can be summarized as urban facilities, health and education opportunities, technological deficiencies.

Although there are important settlements in Ecovillages that are respectful to nature and offer alternative life styles since the 1920s, they may be inadequate in offering all the facilities of a city to the users.

In this study, a model has been developed that is based on ecovillage experiences in Turkey, the conducted survey, and world classifications discussed in the theoretical framework. The Smart Eco-Village Settlement Model, proposed within the scope of the present study, is an intelligent and self-sufficient ecological settlement type which makes use of natural farming and animal husbandry, thus producing its own nutrients, utilizing renewable energy systems, transforming waste, and promoting a collective social life.

The Smart Eco-Village Settlement Model also seeks to establish an alternative new rural life in Turkey by encouraging smart and technological rural settlements and by forming a new production, new education, and new tourism areas as an alternative to urban living style which is disconnected with nature. When designing sustainable living environments, the constitution should be holistic rather than fractional; the solutions to increase the productivity of the process and the threats to the operation of the system should be determined, and the system outputs should be projected. The foremost fundamental objective of the proposed model is to build a settlement which is harmonized with the environment and the existing environmental fabric, which prioritizes the use of local materials, which is environment friendly, and which enriches the existing environmental fabric. Within the scope of the model, it is considered that the EcoVillages which will be built based on distance and population throughout Tur- 
key will be more successful when the number of residents is confined to the maximum number of people each individual might personally know. The construction of new eco-villages is favored by the participants of the survey, although it is likely to be difficult and costly considering the current market dynamics. The reason why the participants are in favor of new eco-villages is that they see it as an alternative way of living and source of income. Among other reasons are the economic gains after the first investment costs thanks to the self-sufficient nature of the settlement and the positive impacts of the alternative energy sources on environmental pollution. Yet another important reason why new eco villages are preferred is the cooperative nature of the settlements which provides that the current villages which are facing the risk of being deserted and abandoned will be on demand again.

Channeling current global economy towards sustainability is a critically important issue to be considered. The proposed Smart Eco-Village Settlement Model, which systematizes the city-village relationship, uses smart technologies, contributes to the economies of the region and the country through various forms of production, ensures sustainable development, and offers an alternative way of living, will ensure the sustainability of the global economy, among other things.

The most important feature of the developed model is to construct an approach that takes into account the traditions, customs, lifestyle and habits of the people living in the region to be planned, depending on the demographic, socioeconomic characteristics, and the characteristics of the built environment that differ in each country and combine the findings of the survey research with the systematic of planning. The above-mentioned features should be handled depending on each country and region and a holistic system should be established.

This study is aimed to be an example that encourages the education of organic agriculture and cultural exchange activities. Strengthening the economy, achieving brand size, producing export growth and boosting employment are the goals of this study. With the proposed eco-village model, a sustainable community that can blend modern needs and lifestyles and reflect our existence in life will emerge. While creating these models, determining ideals, goals and social parameters both individually and as a group is expected to give good results.

\section{Acknowledgements}

This paper was developed from the findings of a research project in Istanbul Technical University, Housing Research and Education Center.

\section{Conflicts of Interest}

The authors declare no conflicts of interest regarding the publication of this paper.

\section{References}

Adalılar, S. N., Alkıbay, S., \& Eser, Z. (2015). Ecovillages as a Destination and a Study of Consumer Approaches to Ecovillages. Procedia Economics and Finance, 23, 539-546. 
https://doi.org/10.1016/S2212-5671(15)00561-4

Akoğlu, A. Z., Yirmibeşoğlu, F., Özmen, E., Baykara, N., Çınar, H. S., Kuruoğlu, M., \& Baslo, M. (2019). Akıllı eko-köy yerleşim modeli. Prof. Dr. Nuran Zeren Gülersoy ile Planlama, Koruma ve Tasarım Üzerine Sempozyumu, İTÜ Mimarlık Fakültesi, Taşkışla, 25 Kasım 2019.

Asımgil, B. (2017). XVI. Yüzyıldan günümüze eko-köylerin tanımlama yaklaşımlarına göre karakteristik özelliklerinin saptanması. Trakya University Journal of Engineering Sciences, 18, 95-111.

Aydın Yönet, N., \& Yirmibeşoğlu, F. (2019). Kırsal kalkınma modeli olarak ekoturizm: Şeyhli ekoturizm köyü (Giresun Piraziz). 6. Uluslararası Multidisipliner Çalışmaları Kongresi. Hasan Kalyoncu Üniversitesi. Gaziantep.

Barton, H. (Ed.) (2000). Sustainable Communities: The Potential for Eco-Neighborhoods. Earthscan.

Barton, H., Marcus, G., \& Richard, G. (2003). Shaping Neighborhoods: A Guide for Health, Sustainability and Vitality (pp. 136-144). Taylor and Francis, Spon Press.

Cebir, G. İ., Eskidemir, K., Başcan, S., Yirmibeşoğlu, F., Baykar, N., \& Kuruoğlu, M. (2019). Sürdürülebilir Kırsal Yerleşim Oluşturma Bağlamında Bir Eko-Köy Modeli Önerisi. 4. Uluslararası Bilimsel Araştırmalar Kongresi (UBAK).

Chai, Q. M., S.Fu, \& Wen X. Y. (2020). Modelling the Implementation of NDCs and the Scenarios below $2^{\circ} \mathrm{C}$ for the Belt and Road Countries. Ecosystem Health and Sustainability, 6, Article ID: 1766998. https://doi.org/10.1080/20964129.2020.1766998

Çınar, H. S., Aytaç, G., \& Yıldız, Ç. (2019). The Settlement Designed within the Scope of the Eco-Village Project. I.T.U Housing Research and Education Center, Taşkışla.

Dias, M. A., Loureiro, C. F. B., \& Souza, C. M. (2017). The Meaning and Relevance of Ecovillages for the Construction of Sustainable Societal Alternatives. Ambiente \& Sociedade, 20, 79-96. https://doi.org/10.1590/1809-4422asoc0083v2032017

Erdinç, E., \& Kariptaş, F. S. (2015). Kentlerden yorulan insanların kaçış alanları EkoKöyler. Yeşil Bina Dergisi.

http://www.yesilbinadergisi.com/edergi/21/50/index.html

Gaia Education (2006). Ecovillage Design Education Curriculum. Findhorn.

Giani, A. (2011). Novelties, Retro-Innovation and Fantacy: Torri Superiore Ecovillage as a Form Resistance to the Abandonment of Rural Marginal Areas in Italy. Master Thesis, Department of Social Sciences, Wageningen University.

Gilman, R. (2015). The Eco-Village Challenge. In Context: Living Together, Sustainable Community Development. Context Institute. http://www.context.org/iclib/ic29/gilman1/

Gilman, R., \& Gilman, D. (1991). Ecovillages and Sustainable Communities. A Report for Gaia Trust by Context Institute.

Güleryüz, M. (2013). Bir ütopya hareketi olarak Eko-köyler: Türkiye'deki örnekler üzerine bir inceleme. Master Thesis, Graduate School of Science Engineering and Technology, Department of Architecture, Istanbul Culture University, 12.

Jackson, H. (1998). What Is an Ecovillage? Gaia Trust Education Seminar, September 1998. https://www.gaia.org/gaia/ecovillage/whatis/

Jackson, H., \& Svensson, K. (2002). Ecovillage Living: Restoring the Earth and Her People. Devon.

Kara, E. (2014). Ekolojik kaygı temelli yerleşimlerde sürdürülebilirlik paradigmasının farklı boyutlarıyla incelenmesi: Eko-köyler. Master Thesis, Istanbul Technical University. 
Kuruoğlu, M., Başcan, S., Eskidemir, K., Cebir, G. İ., Yirmibeşoğlu, F., \& Baykara, N. (2019). Ecovillages as Sustainable Placement Types: A Model Search for Turkey. ISBS 2019, 4th International Sustainable Buildings Symposium, Dallas, TX, 18-20 July 2019, 385-403. https://www.scribd.com/\%20document/442131699/69343-pdf

Meijering, L. (2006). Making a Place of Their Own: Rural Intentional Communities in Northwest Europe. Ph.D Thesis, Groningen: University of Groningen.

Meijering, L., Hoven, B., \& Huigen, P. (2007). Constructing Ruralities: The Case of the Hobbitstee, Netherlands. Journal of Rural Studies, 23, 357-366. https://doi.org/10.1016/j.jrurstud.2007.01.002

Moravčíková, D., \& Fürjészová, T. (2018). Ecovillage as an Alternative Way of Rural Life: Evidence from Hungary and Slovakia. European Countryside, 10, 693-710. https://doi.org/10.2478/euco-2018-0038

Smith, M. E., Engquist, A., Johnston-Zimmerman, C. K., Algara, M., Gilliland, B., Kuznetsov, Y., \& Young, A. (2014). Neighborhood Formation in Semi-Urban Settlements. Journal of Urbanism: International Research on Placemaking and Urban Sustainability, 8, 173 198. https://doi.org/10.1080/17549175.2014.896394

Takeuchi, K., Namiki, Y., \& Tanaka, H. (1998). Designing Eco-Villages for Revitalizing Japanese Rural Areas. Ecological Engineering, 11, 177-197. https://doi.org/10.1016/S0925-8574(98)00031-7

Tuğun, Ö., \& Karaman, A. (2014). Çekirdek köylerin ekoturizme kazandırılması için sürdürülebilirlik kavramı çerçevesinde bir model. Megaron, 9, 321-337. https://doi.org/10.5505/megaron.2014.96268

Westskog, H., Winther, T., \& Aasen, M. (2018). The Creation of an Ecovillage: Handling Identities in a Norwegian Sustainable Valley. Sustainabilty, 10, 2074. https://doi.org/10.3390/su10062074

Zeybek, O. (2014). Eğitim turizminde yeni bir alan: Ekoköyler. III. Disiplinlerarası Turizm Araştırmaları Kongresi, Kuşadası, Aydın, 4-5 July 2014, 758-771.

Zhang, L., Chen, M., \& Teng, F. (2020). Greenhouse Gas (GHG) Emission Mitigation and Ecosystem Adaptation along Belt and Road Initiative. Ecosystem Health and Sustainability, 7, Article ID: 1868272. https://doi.org/10.1080/20964129.2020.1868272

Zhao, C., Yan, Y., Wang, C., Tang, M., Wu, G., Ding, D., \& Song, Y. (2018). Adaptation and Mitigation for Combating Climate Change-From Single to Joint. Ecosystem Health and Sustainability, 4, 85-94. https://doi.org/10.1080/20964129.2018.1466632

URL 1 (2019). https://www.gaia.org/

URL 2 (2019). https://ecotopianetwork.wordpress.com/2010/01/03/ekolojik-koyler-insanin-dogal-yap isina-donme-denemeleri/

URL 3 (2019). https://www.create.green/program/edc

URL 4 (2019). https://ecovillage.org/projects/

URL 5 (2019). https://www.bugday.org/portal/hakkimizda.php/

URL 6 (2019). https://www.wearethehippies.com/turkiyedeki-ekokoy-girisimleri/

URL 7 (2019). https://gaiadergi.com/ekokoyler-icin-yer-secimi-mevzusu-nereye-kurmali/

URL 8 (2019). http://www.bugday.org/portal/haber detay.php?hid=3776

URL 9 (2019). http://www.dogadernegi.org

URL 10 (2019). https://marmaric.org/ 